Arina Banga, Esther Hanssen, Robert Schreuder and Anneke Neijt

\title{
Two languages, two sets of interpretations: Language-specific influences of morphological form on Dutch and English speakers' interpretation of compounds
}

\begin{abstract}
The present study investigates linguistic relativity. Do form differences between Dutch and English influence the interpretations which speakers have? The Dutch element en in noun-noun compounds, for example in aardbeienjam 'strawberry jam' is homophonous and homographic with the regular plural suffix -en. English, in contrast, has no such typical linking elements in compounds. We therefore investigated the interpretation of Dutch modifiers in compounds and their English equivalents. We compared the plurality ratings of Dutch modifiers with and without the linking element en by native Dutch speakers, and the plurality ratings of English modifiers by native Dutch speakers and native English speakers. If the Dutch linking en induces plural meaning, we expected a difference between the plurality ratings by English speakers for English modifiers and by Dutch speakers for Dutch modifiers, such that the estimation of the number of strawberries in strawberry jam is lower for the English speakers than the number of aardbeien in aardbeienjam for the Dutch speakers. This is exactly what we found. Moreover, when native Dutch speakers rate the English equivalents, their interpretation of strawberry jam is the same as for native English speakers, which shows the language being used to influence semantic interpretations.
\end{abstract}

Keywords: Linguistic relativity, Noun-noun compounds, Linking elements, $\mathrm{Nu}$ merosity, Morphology, Dutch, English, Bilingual speakers

\footnotetext{
Arina Banga: Centre for Language Studies, Radboud University Nijmegen, The Netherlands E-mail: arinabanga@gmail.com

Esther Hanssen: Radboud University Nijmegen

Robert Schreuder: Radboud University Nijmegen

Anneke Neijt: Radboud University Nijmegen
} 


\section{Introduction}

Humans use more than 6000 languages to communicate with each other (Lewis 2009). Languages differ with respect to phonology, morphology and syntax which can in turn influence the way in which speakers interpret the world. In the present research, we investigated this phenomenon by examining the linking element en in Dutch noun-noun compounds, the English equivalents and perceptions of numerosity. By "linking element," we mean the element between the two constituents, the modifier and the head, respectively, of a noun-noun compound. ${ }^{1}$ An example of this linking element is en in the compounds boekenkast 'book + en + case' and sterrenstelsel 'star + en + system'. The Dutch linking element en has the same form as the plural suffix -en in, for example, boeken 'books'. In order to answer the question of whether the form similarity in Dutch and the form dissimilarity in English influences speakers' understanding of the modifier, we compared the plurality ratings for Dutch modifiers with those for English modifiers. And we indeed found a clear interplay between form, native language and interpretation.

In the 19th century, Wilhelm von Humboldt connected language differences to differences in thought, assuming that thinking is an inner dialog using the thinker's native language (Von Humboldt 1836; Losonsky 1999: xvi). In his view, just as sound differs from language to language, the conceptual part of language differs from language to language as well (Trabant 2000). That is, the diversity of languages represents not only a diversity of sounds (or signs in sign language) but also a diversity of world views (Losonsky 1999: xvii).

More than 75 years after Von Humboldt, Edward Sapir followed this idea:

No two languages are ever sufficiently similar to be considered as representing the same social reality. The worlds in which different societies live are distinct worlds, not merely the same world with different labels attached. (Sapir 1985 [1949])

Sapir's student Benjamin Lee Whorf was also convinced of the influence of language on thought and compared languages to find evidence for this (Whorf 1956).

Nowadays, both linguists and psychologists are again paying attention to the idea that language might influence thought (Boroditsky 2003). Research on

1 Some linguists, such as Bauer (2003) and Booij (2007), reserve the term “linking element” for only elements which cannot have a plural meaning. We use the term to indicate the form of the element irrespective of its meaning. 
linguistic relativity has concentrated on specific areas of language and cognition, namely: spatial relations (Bowerman and Choi 2007; McDonough et al. 2003); time (e.g., Boroditsky 2001; Boroditsky et al. 2011; but see January and Kako 2007 and Chen 2007 for unsuccessful attempts to replicate Boroditsky's 2001 findings); colour (Roberson et al. 2000; Roberson et al. 2004); material and shape (Lucy 1992); number (Gumperz and Levinson 1997); and objects (Miwa et al. 2008).

The influence of language on conceptualization is strikingly illustrated by the research of Roberson et al. (2004) who found different categorical perception effects for languages with the same number of colour words referring to nevertheless different categories of colour. The participants in this study were native speakers of Himba, a dialect spoken by an isolated tribe in Namibia. In Himba, there are only five colour names of which dumbu (shades of green, red, brown and yellow) and burou (other shades of green and blue) were studied by Roberson et al. When the speakers of Himba carried out similarity judgments, they showed only categorical perception for their own linguistic categories and not the linguistic categories of English or the Berinmo language, which is also a language with only five colour names but different categories of colour associated with them, presumably due to a different environment. These results led Roberson et al. to conclude that linguistic categorization is isomorphic with cognitive representation.

In the present research, we aimed to extend the evidence for linguistic relativity to perceptions of numerosity and the role of the linking element en in Dutch noun-noun compounds. As already mentioned, Dutch compounds can have a linking element which is written as en (e.g., boekenplank 'book + en + shelf') and takes the same form as the -en plural suffix (e.g., boeken 'books'). Such homography raises the question of whether the linking en and plural suffix -en are perceived as related (i.e., both conveying plural meaning, see for example Schreuder et al. 1998), or unrelated (Booij 2007; Verkuyl 2007). And the form differences between Dutch and English compounds allow us to investigate the answer to this question: Does the homographic linking element indeed influence ratings of plurality when native speakers versus second language speakers are compared? We expected native speakers of English to provide lower plurality ratings for modifiers when presented the English translation equivalents of words written with a linking en in Dutch compared to native Dutch speakers in the Dutch version of the experiment. We also wondered if similar results might be found for second language speakers. That is, when native speakers of Dutch with English as a second language are asked to rate the English translation equivalents of Dutch compounds, they could either follow the interpretation pattern of their native Dutch or the interpretation pattern of English. Our prediction was that native English 
speakers when rating strawberry jam would consider this jam to contain fewer strawberries than native Dutch speakers rating the same English modifiers, despite the similarity of cultures and strawberry jam / aardbeienjam being essentially the same for the speakers of these two languages.

Schreuder et al. (1998) claim that the Dutch linking element en and the Dutch plural suffix -en are associated with each other by native speakers and show that one consequence of the spelling change of 1996 - where the former linking element $e$ was changed to en, which is homographic with the plural suffix - has been an increase in the activation of plural semantics. When asked to indicate whether a compound was singular or plural as quickly and accurately as possible, a task that requires one to attend to only the final syllable of the compound (i.e., not to the modifier) ending on the plural suffix -en or not (slangebeet/slangenbeet 'snakebite' versus slangebeten/slangenbeten 'snakebites'), Dutch participants were nevertheless influenced by the en in the middle of the compound. Thus, the presence of a linking en, rather than $e$, slowed response times for number decisions (i.e., the singular response to slangenbeet 'snakebite' was slower than the singular response to slangebeet 'snakebite'). This interference effect indicates automatic activation of plural semantics and shows that the respondents were not able to ignore the word-internal linking element. Studies by Hanssen et al. (submitted), Banga et al. (in press) and Neijt et al. (2002) have similarly shown plural meaning to be involved in the processing and production of linking en in Dutch noun-noun compounds.

The aim of the present study is thus to determine if the homography of the Dutch linking element en and the Dutch plural suffix -en influences the way in which native speakers of Dutch rate the first part of the compound on the dimension of numerosity. In one study, we investigated the response patterns of native speakers of Dutch and native speakers of English to see if their ratings of plurality differed. In a second study, we compared the two sets of numerosity ratings to the numerosity ratings of native Dutch speakers performing the English version of the experiment and thus responding in a second language.

\section{Study 1: Dutch and English as native languages}

The main question in this study was if the numerosity judgements of Dutch and English speakers would differ when rating the plurality of the modifiers of culturally shared items. This study was thus carried out in Dutch for native Dutch speakers and in English for native English speakers. 


\subsection{Method}

\subsubsection{Participants}

Two groups of participants took part in the experiment. The first group consisted of 42 adult native Dutch speakers (mean age $M=21$ years, standard deviation $S D=2.2$ ). They were undergraduates at the Radboud University Nijmegen and participated in the study as part of a course. The second group consisted of 42 adult native English speakers $(M=19$ years, $S D=0.8)$. They were undergraduates at the university of Sheffield and participated in the study as part of a course as well.

\subsubsection{Materials}

The Dutch experiment consisted of 105 everyday Dutch noun-noun compounds; 54 with linking element en and 51 without linking element en. ${ }^{2}$ These form types could be divided into two conceptual types: the modifier of the compound was either conceptually singular (e.g., bananenschil 'banana skin' and ballonvaart 'balloon ride') or conceptually plural (e.g., aardbeienjam 'strawberry jam' and appeltaart 'apple pie'). The classification into these conceptual types was done by three independent linguists, who were asked to indicate whether they considered the modifier as 'singular', 'plural' or 'do not know'. They agreed on $66 \%$ of the items. All of the items on which the judges did not agree were excluded from the analysis.

The test items thus contained four types of items: conceptually singular with a linking en (14 items), conceptually plural with a linking en (25 items), conceptually singular without a linking en (17 items) and conceptually plural without a linking en (14 items).

The different types of items were randomized in two different orders. One order resulted in two versions of the experiment: the order itself and the reversed order. In total, four versions of the experiment were used. The materials are listed in Appendix A.

2 Whether a certain lexicalized compound needs a linking en or not, depends on convention. Whether a novel compounds needs a linking en or not, depends a.o. on paradigmatic analogy (Krott et al. 2001) and prosody (Neijt and Scheuder 2007; Hanssen et al. in press). However, in the present study, only the standard forms of lexicalized compounds were used. 


\subsubsection{Procedure}

All participants performed a paper- and-pencil task, which was to rate the plurality of the modifiers in the presented compounds along a 7-point scale. This was used because some modifiers containing a plural concept may evoke higher plural interpretations than other modifiers containing a plural concept. Speakers, for example, may have different plurality intuitions for an anthill / mierenhoop, which entails a lot of ants, versus a shoe box / schoenendoos, which entails a pair (two) of shoes. They were asked to mark the circle on the left if the modifier had a singular meaning and a circle to the right of this if the modifier had a plural meaning; the location of the circle to the right indicated the degree of plurality for the target word. The participants were asked to rely on their intuitions when rating the plurality of 105 modifiers in compounds, 70 of which were included in the analyses (see Section 2.1.2 and Appendix B for the instructions). Note that the participants were free to use the extreme values if - according to them - plurality can only be referred to as a dichotomy between singular and plural instead of a scale, although they were not explicitly instructed to do this. Prior to the experiment, the participants completed a questionnaire which asked for such basic information as their age and mother tongue. Completion of the task took about 15 minutes.

\subsection{Results}

The average ratings and standard deviations provided for the four types of Dutch items (with linking en and without, conceptually singular and plural) by the native Dutch speakers and the English translation equivalents by the native English speakers are presented in Table 1 and Figure 1.

General Linear Model Repeated Measures ANOVAs were conducted with Concept (singular or plural) and Form (presence or absence of linking en) as withinparticipants and within-items factor and Language as a between-participants factor. The English modifiers did not contain a linking element but, to gain insight into the semantics of the Dutch linking en, we compared the English translation equivalents for the four types of Dutch modifiers to the Dutch modifiers which either did or did not contain the linking element en. A significant main effect of Form was found, $F_{1}(1,82)=38.149, M S E=1.229, p<.001$ and $F_{2}(1,26)=36.59$, $M S E=0.528, p<.001$. Those modifiers containing linking en were rated as more plural $(M=3.9)$ than those without linking en $(M=3.2)$. Separate analyses for each group of participants showed this main effect to be caused by the native Dutch speakers, $F_{1}(1,41)=36.7, M S E=2.353, p<.001$ and $F_{2}(1,13)=121.1, M S E=$ 
Table 1: Mean ratings (standard deviations) provided by native Dutch and English speakers for modifiers referring to inherently singular or plural concepts ( $1=$ singular; $7=$ extremely plural).

\begin{tabular}{|c|c|c|c|}
\hline \multicolumn{4}{|c|}{ Modifier with linking en } \\
\hline \multicolumn{2}{|c|}{ Conceptually singular } & \multicolumn{2}{|c|}{ Conceptually plural } \\
\hline Dutch modifiers & English modifiers & Dutch modifiers & English modifiers \\
\hline $\begin{array}{l}\text { Native Dutch } \\
\text { speakers } \\
2.96(1.56)\end{array}$ & $\begin{array}{l}\text { Native English } \\
\text { speakers } \\
2.67(0.81)\end{array}$ & $\begin{array}{l}\text { Native Dutch } \\
\text { speakers } \\
5.85(0.92)\end{array}$ & $\begin{array}{l}\text { Native English } \\
\text { speakers } \\
4.10(1.14)\end{array}$ \\
\hline \multicolumn{4}{|c|}{ Modifier without linking en } \\
\hline \multicolumn{2}{|c|}{ Conceptually singular } & \multicolumn{2}{|c|}{ Conceptually plural } \\
\hline Dutch modifiers & English modifiers & Dutch modifiers & English modifiers \\
\hline $\begin{array}{l}\text { Native Dutch } \\
\text { speakers }\end{array}$ & $\begin{array}{l}\text { Native English } \\
\text { speakers }\end{array}$ & $\begin{array}{l}\text { Native Dutch } \\
\text { speakers }\end{array}$ & $\begin{array}{l}\text { Native English } \\
\text { speakers }\end{array}$ \\
\hline $1.83(0.69)$ & $2.53(0.69)$ & $4.11(1.58)$ & $4.12(1.24)$ \\
\hline
\end{tabular}

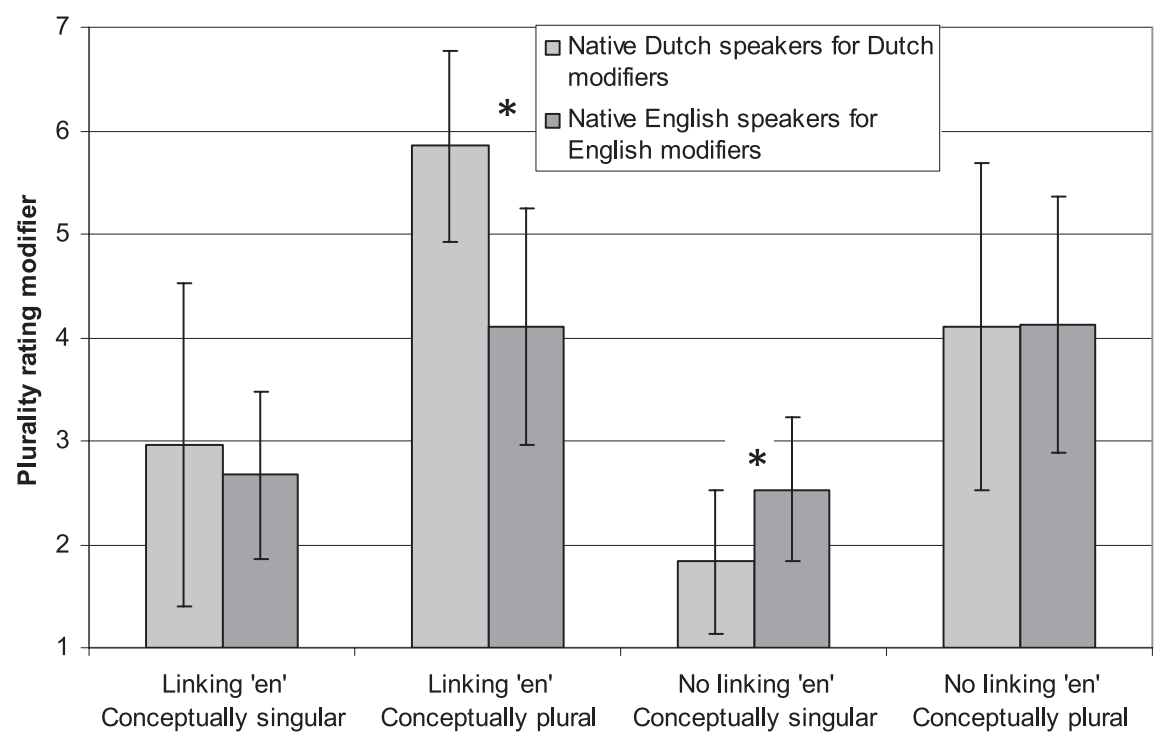

Type of modifier

Fig. 1: Mean ratings (standard deviations) provided by native Dutch and English speakers for modifiers referring to inherently singular or plural concepts $(1=$ singular; $7=$ extremely plural $)$ 
0.280, $p<.001$; this main effect was not found for the native English speakers. Thus, an interaction between Form and Language occurred as well, $F_{1}(1,82)=$ $32.314, p<.001$ and $F_{2}(1,26)=23.67, p<.001 .^{3}$

A significant main effect of Concept was also found, $F_{1}(1,82)=209.635$, $M S E=1.678, p<.001$ and $F_{2}(1,26)=259.72, M S E=0.487, p<.001$. Those modifiers referring to inherently plural concepts were indeed rated as more plural $(M=4.5)$ than those referring to inherently singular concepts $(M=2.5)$. Separate analyses for each group of participants showed this main effect to be caused by the responding of both groups of participants: $F_{1}(1,41)=124.0, M S E=2.259, p<.001$ and $F_{2}(1,13)=396.0, M S E=0.247, p<.001$ for native Dutch speakers; $F_{1}(1,41)=87.4$, $M S E=1.097, p<.001$ and $F_{2}(1,13)=49.7, M S E=0.727, p<.001$ for native English speakers. A significant interaction between Concept and Language was found, $F_{1}(1,82)=14.370, p=.001$ and $F_{2}(1,26)=15.54, p=.001$.

A significant interaction between Form and Concept was found, $F_{1}(1,82)=$ 5.265, $M S E=0.197, p=.024$ and $F_{2}(1,26)=0.785, M S E=0.532, p=.384$, in addition to a significant interaction between Concept, Form and Language, $F_{1}(1,82)=15.376$, $p<.001$ and $F_{2}(1,26)=1.850, p=.185$. Given that language is a significant factor in the comparison of the English and Dutch data, we first discuss the interaction from this language-point of view. For the modifiers without linking en and a singular concept, the native Dutch speakers in the Dutch version of the experiment rated them less plural $(M=1.8)$ than the native English speakers in the English version of the experiment $(M=2.5), t_{1}(38)=3.695, p=.001, t_{2}(14)=1.654, p=.122$. For the modifiers with linking en and a singular concept, no differences were found between the groups of participants. This was also found to be the case for the modifiers without linking en and a plural concept. However, for the modifiers with linking en and a plural concept, the native Dutch speakers in the Dutch version of the experiment rated the modifiers as more plural $(M=5.9)$ than the native English speakers in the English version of the experiment $(M=4.1), t_{1}(38)=6.612$, $p<.001, t_{2}(24)=10.610, p<.001$.

The native Dutch speakers rated the modifiers with a singular concept as more plural when the modifier contained the linking element en (mean =3.0) as

3 We also did an analysis for the factor Form with all the 105 items. The results were the same as for the subset of the items in the main text. There was a main effect for Form, $F_{1}(1,82)=50.035$, $M S E=0.566, p<.001$ and $F_{2}(1,100)=22.988, M S E=1.593, p<.001$, and an interaction between Form and Language, $F_{1}(1,82)=57.232, p<.001$ and $F_{2}(1,100)=24.265, p<.001$. Also for the analysis with all 105 items, separate analyses for each group of participants showed the interaction between Form and Language to be caused by the ratings provided by the native Dutch speakers, $t_{1}(41)=7.442, p<.001$ and $t_{2}(50)=6.642, p<.001$, such an effect was not found for the native English speakers, $t_{1}(41)=1.359, p=.182$ and $t_{2}(50)=0.096, p=.924$. 
opposed to no such element $(M=1.8)$. This was also the case for modifiers with a plural concept (linking element en: $M=5.9$, no such element: $M=4.1$ ). For the native English speakers, no significant differences were found between the numerosity judgements for the translation equivalents with conceptually singular modifiers with and without linking element en in the Dutch translation equivalents, neither between the translation equivalents with conceptually plural modifiers with and without the linking element en in the Dutch.

\subsection{Discussion}

In Study 1, native Dutch speakers were compared to native English speakers to determine if the presence of the linking en which is homographic with the Dutch plural -en suffix influences the ratings of numerosity by the Dutch speakers in particular. This is exactly what we found. For conceptually plural modifiers accompanied by a linking en, the Dutch ratings of numerosity were higher than the English ratings; for conceptually singular modifiers without a linking en, the English ratings of numerosity were higher than the Dutch ratings. For the other two types of modifiers, no significant differences were found. Note that the native English speakers did not rate all modifiers as singular, presumably due to their knowledge of the world: Speakers know that strawberry jam contains more than one strawberry irrespective of linguistic marking of such information.

The findings from Study 1 further show the influence of Form (i.e., presence or absence of linking en) on the native Dutch speakers' ratings of numerosity to be constrained by the influence of Concept. While the native Dutch speakers could have interpreted the factor Form as a sign of singular or plural more or less across the board, they did not. They were found to respond the same as the native English speakers when the Dutch form information was in conflict with the conceptual information. As expected, the native English speakers were not influenced by the factor Form, which only was present in the Dutch version of the experiment. That is, conceptually plural modifiers without a linking en and conceptually singular modifiers with a linking en were rated the same.

For native Dutch speakers, the factor Form appears to strengthen the factor Concept resulting in 'super plural' interpretations for conceptually plural modifiers with linking en and 'super singular' interpretations for conceptually singular modifiers without linking en. In other words, native Dutch speakers appear to interpret linking en to be a sign of plural meaning and this shows language to influence the interpretation of everyday noun-noun compounds. However, we 
could not determine if the influence of language on the Dutch speakers' perceptions of numerosity was caused by their native Dutch knowledge or the Dutch used in the experiment. This is why we carry out the English experiment with responding of native Dutch speakers when presented with materials in English (i.e., a second language). This way, we investigated whether their plurality ratings would resemble the responding of the native Dutch speakers in Study 1 or the responding of the native English speakers in Study 1. If the responding of the native Dutch speakers when presented English translation equivalents is the same as the responding of native Dutch speakers when presented Dutch stimuli, then their responding in English is presumably caused by their native Dutch knowledge (i.e., the influence of their internalized Dutch knowledge). If the responding of the native Dutch speakers when presented English translation equivalents is the same as the responding of the native English speakers when presented the same English translation equivalents, then the responding of the Dutch native speakers is presumably caused by the language itself (i.e., the language of the experiment itself, namely English).

\section{Study 2: English as a second language}

\subsection{Method}

A third group of participants took part in Study 2: 40 adult native speakers of Dutch $(M=23$ years, $S D=3.0)$. They were undergraduates at the Radboud University Nijmegen and participated voluntarily. Their task was the same as for the native English speakers: They were asked to rate the plurality of the modifiers in the English translation equivalents for the Dutch compounds. All of the participants, just as Dutch students in general and those in Study 1, had a fairly high level of English as a second language.

\subsection{Results}

We first compared the plurality ratings provided by the native Dutch speakers for the English modifiers (this Section: Study 2) with those provided by the native Dutch speakers for the Dutch modifiers (see Section 2: Study 1). We then compared the plurality ratings provided by the native Dutch speakers for the English modifiers (this Section: Study 2) with those provided by the native English 
Table 2: Mean ratings (standard deviations) provided by native Dutch speakers responding to English modifiers and native Dutch speakers responding to Dutch modifiers for four types of items ( 1 = singular; 7 = extremely plural).

\begin{tabular}{|c|c|c|c|}
\hline \multicolumn{4}{|c|}{ Modifier containing linking en } \\
\hline \multicolumn{2}{|c|}{ Conceptually singular } & \multicolumn{2}{|c|}{ Conceptually plural } \\
\hline English modifiers & Dutch modifiers & English modifiers & Dutch modifiers \\
\hline $\begin{array}{l}\text { Native Dutch } \\
\text { speakers }\end{array}$ & $\begin{array}{l}\text { Native Dutch } \\
\text { speakers }\end{array}$ & $\begin{array}{l}\text { Native Dutch } \\
\text { speakers }\end{array}$ & $\begin{array}{l}\text { Native Dutch } \\
\text { speakers }\end{array}$ \\
\hline \multicolumn{4}{|c|}{ Modifier without linking en } \\
\hline \multicolumn{2}{|c|}{ Conceptually singular } & \multicolumn{2}{|c|}{ Conceptually plural } \\
\hline English modifiers & Dutch modifiers & English modifiers & Dutch modifiers \\
\hline $\begin{array}{l}\text { Native Dutch } \\
\text { speakers }\end{array}$ & $\begin{array}{l}\text { Native Dutch } \\
\text { speakers }\end{array}$ & $\begin{array}{l}\text { Native Dutch } \\
\text { speakers }\end{array}$ & $\begin{array}{l}\text { Native Dutch } \\
\text { speakers }\end{array}$ \\
\hline $2.49(0.84)$ & $1.83(0.69)$ & $4.45(1.17)$ & $4.11(1.58)$ \\
\hline
\end{tabular}

speakers for the English modifiers (see Section 2: Study 1). The plurality ratings for four types of items were thus analyzed: conceptually singular items with a linking en; conceptually plural items with a linking en; conceptually singular items without the linking element; and conceptually plural items without the linking element.

In Table 2 and Figure 2, the average ratings and standard deviations provided by the native Dutch speakers responding to the English modifiers (this Section: Study 2) and the native Dutch speakers responding to the Dutch modifiers (see section 2: Study 1) are presented for the four types of items.

General Linear Model Repeated Measures ANOVAs were conducted with Concept (singular or plural) and Form (presence or absence of linking en) as withinparticipants and within-items factors and Language as a between-participants factor. A significant main effect of Form was found, $F_{1}(1,88)=37.35, M S E=1.270$, $p<.001$ and $F_{2}(1,26)=43.72, M S E=0.528, p<.001$. Those modifiers containing linking en were rated as more plural $(M=4.0)$ than those modifiers without linking en $(M=3.2)$. Separate analyses for each group of participants showed that this main effect was caused by the native Dutch speakers rating the Dutch modifiers, $F_{1}(1,41)=36.7, M S E=2.353, p<.001$ and $F_{2}(1,13)=121.1, M S E=0.280, p<.001$; no effect was found for the native Dutch speakers rating the English modifiers. A 


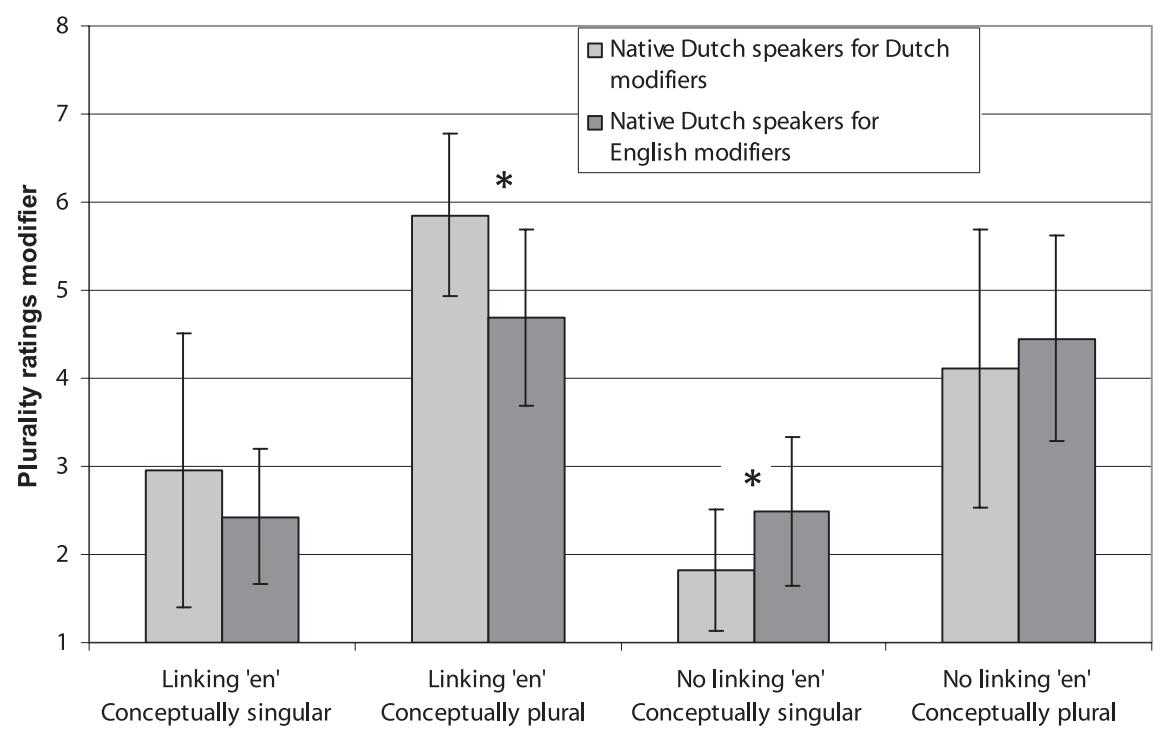

Type of modifier

Fig. 2: Mean ratings (standard deviations) provided by native Dutch speakers responding to English modifiers and native Dutch speakers responding to Dutch modifiers for four types of items ( 1 = singular; 7 = extremely plural)

significant interaction between Form and Language thus occurred as well, $F_{1}(1,88)=32.31, p<.001$ and $F_{2}(1,26)=22.47, p<.001 .{ }^{4}$

A significant main effect of Concept was found, $F_{1}(1,88)=209.6, M S E=2.035$, $p<.001$ and $F_{2}(1,26)=602.4, M S E=0.277, p<.001$. Those modifiers referring to plural concepts were indeed rated as more plural $(M=4.8)$ than those modifiers referring to singular concepts $(M=2.4)$. Separate analyses for each group of participants showed this main effect to be caused by the responding of both groups, $F_{1}(1,41)=124.0, M S E=2.259, p<.001$ and $F_{2}(1,13)=396.0, M S E=0.247, p<.001$ for

4 We also did an analysis for the factor Form with all the 105 items. The results were the same as for the subset of the items. There was a main effect for Form, $F_{1}(1,80)=58.995, M S E=0.590$, $p<.001$ and $F_{2}(1,100)=34.79, M S E=1.270, p<.001$, and an interaction between Form and Language, $F_{1}(1,80)=42.023, p<.001$ and $F_{2}(1,100)=24.91, p<.001$. Also for the analysis with all the 105 items, separate analyses for each group of participants showed that this interaction was caused by the native Dutch speakers rating the Dutch modifiers, $t_{1}(41)=7.442, p<.001$ and $t_{2}(50)=6.642, p<.001$, whereas this effect was not found for the native Dutch speakers rating the modifiers in the English version of the experiment, $t_{1}(39)=2.649, p=.120$ and $t_{2}(50)=0.792$, $p=.432$. 
native Dutch speakers rating Dutch modifiers; and $F_{1}(1,39)=98.6, M S E=1.800$, $p<.001$ and $F_{2}(1,13)=228.6, M S E=0.307, p<.001$ for native speakers of Dutch rating English modifiers. A significant interaction between Concept and Language occurred as well, $F_{1}(1,88)=14.37, p<.001$ and $F_{2}(1,26)=4.16, p=.052$. The Dutch participants rated the English conceptually singular modifiers as more plural than the Dutch conceptually singular modifiers. Conversely, they rated the Dutch conceptually plural modifiers as more plural than the English conceptually plural modifiers.

A significant interaction between Form and Concept was also found, $F_{1}(1,88)=$ $5.265, M S E=0.145, p=.024$ and $F_{2}(1,26)=4.71, M S E=0.376, p=.039$, in addition to a significant interaction between Concept, Form and Language, $F_{1}(1,88)=15.38$, $p<.001$ and $F_{2}(1,26)=0.251, p=.620$.

For the native Dutch speakers asked to perform the English version of the experiment, no differences were found in their responding to the conceptually singular translation equivalents which would either have a linking element in Dutch or no such linking element; there were also no difference in their responding to the conceptually plural translation equivalents which would either have a linking element in Dutch or no such linking element (Bonferroni correction). As already mentioned, for the native Dutch speakers performing the Dutch version of the experiment (see Section 2: Study 1), the conceptually singular modifiers and conceptually plural modifiers were both rated more extremely when they contained the matching linking element: no linking en in the case of the singular and the linking en in the case of the plural.

For the conceptually singular modifiers with no linking en, the ratings provided by the native Dutch speakers in the Dutch version of the experiment were lower (mean $=1.83$ ) than the ratings provided by the native Dutch speakers in the English version of the experiment $(M=2.49), t_{1}(38)=4.212, p<.001, t_{2}(14)=3.842$, $p=.001$ (one-tailed). For the conceptually singular modifiers with linking en, no significant differences were found between the Dutch and English versions of the experiment. There were also no significant differences found for the responding of the two groups to the conceptually plural modifiers without a linking en. However, for the conceptually plural modifiers with a linking en, the native speakers of Dutch rated the modifiers in the Dutch version of the experiment as more plural $(M=5.85)$ when compared to the native speakers of Dutch in the English version of the experiment $(M=4.69), t(38)=5.399, p<.001, t_{2}(24)=10.610, p<.001$.

In light of the many differences found for the responding of the native Dutch speakers in the Dutch versus English versions of the experiment, it appears that the responding of the native Dutch speakers in the English version of the experiment resembles the responding of the native English speakers in the English version of the experiment more than the responding of the Dutch speakers in the 
Table 3: Mean ratings (standard deviations) provided by native Dutch speakers responding to English modifiers and native English speakers responding to English modifiers for four types of items ( 1 = singular; 7 = extremely plural).

\begin{tabular}{|c|c|c|c|}
\hline \multicolumn{4}{|c|}{ Modifier containing linking en } \\
\hline \multicolumn{2}{|c|}{ Conceptually singular } & \multicolumn{2}{|c|}{ Conceptually plural } \\
\hline English modifiers & English modifiers & English modifiers & English modifiers \\
\hline $\begin{array}{l}\text { Native Dutch } \\
\text { speakers }\end{array}$ & $\begin{array}{l}\text { Native English } \\
\text { speakers }\end{array}$ & $\begin{array}{l}\text { Native Dutch } \\
\text { speakers }\end{array}$ & $\begin{array}{l}\text { Native English } \\
\text { speakers }\end{array}$ \\
\hline $2.67(0.81)$ & $2.43(0.77)$ & $4.10(1.14)$ & $4.69(1.00)$ \\
\hline \multicolumn{4}{|c|}{ Modifier without linking en } \\
\hline \multicolumn{2}{|c|}{ Conceptually singular } & \multicolumn{2}{|c|}{ Conceptually plural } \\
\hline English modifiers & English modifiers & English modifiers & English modifiers \\
\hline $\begin{array}{l}\text { Native Dutch } \\
\text { speakers }\end{array}$ & $\begin{array}{l}\text { Native English } \\
\text { speakers }\end{array}$ & $\begin{array}{l}\text { Native Dutch } \\
\text { speakers }\end{array}$ & $\begin{array}{l}\text { Native English } \\
\text { speakers }\end{array}$ \\
\hline $2.53(0.81)$ & $2.49(0.84)$ & $4.12(1.24)$ & $4.45(1.17)$ \\
\hline
\end{tabular}

Dutch version of the experiment. Such a pattern of findings suggests that interpretation is shaped by the forms of the language being used on a given occasion rather than by one's native language.

To test this hypothesis, we next compared the plurality ratings provided by the native Dutch speakers for the English translation equivalents with those provided by the native English speakers for the same English translation equivalents. In Table 3 and Figure 3, the average ratings provided by the native Dutch speakers responding to the English modifiers (this Section: Study 2) and the native English speakers responding to the English modifiers (see Section 2: Study 1) are presented for the four types of items.

General Linear Model Repeated Measures ANOVAs were conducted with Concept (singular or plural) and Form (presence or absence of linking en) as a withinparticipants and within-items factor and Language as a between-participants factor. No main effect of Form was found, $F_{1}(1,80)=3.736, M S E=0.118, p=.057$ and $F_{2}(1,26)=1.60, M S E=0.736, p=.217$, and there was also no significant interaction between Form and Language, $F_{1}(1,80)=0.131, p=.718$ and $F_{2}(1,26)=0.068$, $p=.796 .^{5}$

5 We also did an analysis for the factor Form with all the 105 items. The results were almost the same as for the subset of the items. There was no main effect for Form too, $F_{1}(1,80)=1.615$, 


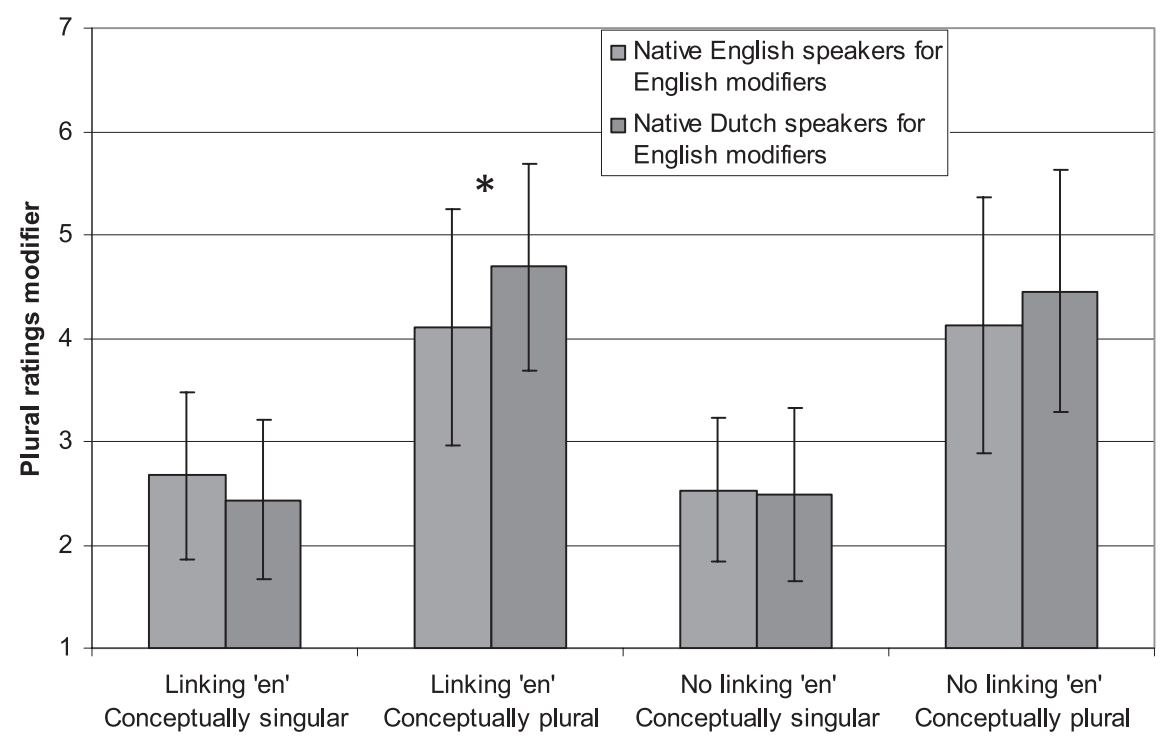

Type of modifier

Fig. 3: Mean ratings (standard deviations) provided by native Dutch speakers responding to English modifiers and native English speakers responding to English modifiers for four types of items ( 1 = singular; 7 = extremely plural)

A significant main effect of Concept was found, $F_{1}(1,80)=186.2, M S E=1.439$, $p<.001$ and $F_{2}(1,26)=260.2, M S E=0.517, p<.001$. Those modifiers referring to plural concepts were indeed rated as more plural $(M=4.3)$ than those modifiers referring to singular concepts $(M=2.5)$. Separate analyses for each group of participants again showed this main effect to be caused by both groups of participants. However, a significant interaction between Concept and Language occurred as well, $F_{1}(1,80)=5.052, p=.027$ and $F_{2}(1,26)=5.44, p=.028$. The English participants rated the English conceptually singular modifiers as more plural than the Dutch participants. Conversely, the Dutch participants rated the conceptually plural modifiers as more plural than the English conceptually plural modifiers.

$M S E=0.048, p=.207$ and $F_{2}(1,100)=0.159, M S E=1.156, p=.691$. There might be a marginal interaction between Form and Language, $F_{1}(1,80)=8.665, p=.004$ and $F_{2}(1,100)=0.305, p=.582$. However, separate analyses for each group of participants showed that this effect disappears when analyzing both groups separately: for the native English speakers rating the English modifiers, $t_{1}(41)=1.359, p=.182$ and $t_{2}(50)=0.096, p=.924$, and for the native Dutch speakers rating the modifiers in the English version of the experiment, $t_{1}(39)=2.649, p=.120$ and $t_{2}(50)=0.792$, $p=.432$. 
No interaction between Form and Concept was found, $F_{1}(1,80)=0.521$, $M S E=0.179, p=.473$ and $F_{2}(1,26)=0.223, M S E=0.514, p=.640$. However, a marginally significant interaction between Concept, Form and Language was found, $F_{1}(1,80)=5.801, p=.018$ and $F_{2}(1,26)=0.913, p=.348$. No differences were found between the two groups for conceptually singular modifiers without linking en, conceptually singular modifiers with linking en or conceptually plural modifiers without linking en. For the conceptually plural modifiers with linking en, however, the native speakers of Dutch rated the English modifiers as more plural $(M=4.69)$ when compared to the native speakers of English $(M=4.10), t_{1}(39)=$ 2.383, $p=.022, t_{2}(24)=4.767, p<.001$.

\subsection{Discussion}

To investigate whether the differences between the native Dutch speakers in the Dutch version of the experiment and the native English speakers in the English version of the experiment of Study 1 were caused by their native language knowledge or by the language of the experiment, we next conducted the English experiment with native Dutch speakers who thus had English as a second language. The ratings provided by the group of Dutch speakers in the English-language experiment (this Section: Study 2) were then compared to the ratings provided in Study 1 (see Section 2).

First, we compared the native Dutch speakers in the English version of the experiment with the native Dutch speakers in the Dutch version of the experiment. No differences were found for the ratings of conceptually singular modifiers with a linking en in Dutch or conceptually plural modifiers without a linking en in Dutch. However, the ratings in the Dutch version of the experiment were higher than in the English version of the experiment for the conceptually plural modifiers with a linking en and lower than in the English version of the experiment for conceptually singular modifiers without a linking en. These findings suggest that the native Dutch speakers did not bring along the semantics of Dutch linking en in their interpretation of the English modifiers.

Second, we compared the native Dutch speakers in the English version of the experiment with the native English speakers in the English version of the experiment to test whether their patterns of responding were similar. With respect to the factor Form, this was the case. The native Dutch speakers interpreted the English modifiers similar to native English speakers, again suggesting that the native Dutch speakers do not bring along the semantics associated with Dutch linking en to interpret English modifiers. Although both groups show a similar pattern 
with respect to Concept, they marginally differ in the degree to which they distinguish conceptually singular modifiers and conceptually plural modifiers. However, they only differ in the interpretation of conceptually plural modifiers with a linking en; the native Dutch speakers produce higher ratings than the native English speakers. Thus, the native Dutch speakers in the English experiment do not interpret this condition the same as the native English speakers or as the native Dutch speakers in the Dutch experiment.

Closer inspection of the English compounds rated by the native Dutch speakers showed the majority of the ratings to reflect the pattern produced by the native English speakers (i.e., be lower than the Dutch ratings), but a small portion of the ratings were found to reflect the pattern produced by the native Dutch native speakers for Dutch modifiers (i.e., higher than the English ratings). Examples of items following the English pattern are banana skin, bookshelf, animal day and dovecote. Examples of items following the Dutch pattern are strawberry jam, rabbit hutch and pin-head.

We globally inspected the frequency of the target word by the naked eye because high frequency English words may be more likely to follow the English pattern for Dutch native speakers than low frequency English words. However, this did not appear to be the case. The Google frequencies for the items rated in accordance with the English pattern by the native Dutch speakers were 125000 (banana skin), 4680000 (bookshelf), 48700 (animal day) and 715000 (dovecote) whereas the Google frequencies for the items rated in accordance with the Dutch pattern were 256000 (strawberry jam), 2600000 (rabbit hutch) and 100000 (pin-head) (for the frequencies, see Appendix A). If the English frequency influenced the response patterns, we would expect the frequencies of the compounds following the Dutch pattern to be lower than the frequencies of the compounds following the English pattern. This was not found to be the case, so the frequency of the English compounds did not apparently influence the responding of native Dutch speakers to the everyday noun-noun compounds included in our study.

These findings show the native Dutch speakers in the English version of the experiment, which relied upon translation equivalents from the Dutch experiment, to differ from the native Dutch speakers in the Dutch experiment. And although their responding also differed from how native English speakers interpreted the conceptually plural modifiers which would take a linking en in Dutch, the response pattern of the native Dutch speakers in the English version of the experiment was most similar to the response pattern of the native English speakers in the English version of the experiment. These findings suggest that interpretation may be influenced by the morphological form available in a language. 


\section{General discussion}

In the present study, we investigated whether different forms for the modifiers in Dutch and English compounds influence speakers' interpretation. We first examined the interpretation of four types of items by native Dutch speakers. The items could be divided into two conceptual types: one in which the modifier of the compound was conceptually singular (e.g., bananenschil 'banana skin' and ballonvaart 'balloon ride') and one in which the modifier was conceptually plural (e.g., aardbeienjam 'strawberry jam' and appeltaart 'apple pie'). These modifiers could be with or without the linking element en in Dutch, which is similar to the plural suffix -en in Dutch. The English translation equivalents for the Dutch compounds were next presented to native English speakers and native Dutch speakers. The plurality ratings by the three groups of participants were then compared.

The native Dutch speakers rated the modifiers as more plural when the compounds contained a linking en than when they did not. No such differences were found for the native English speakers in the English version of the experiment. Given that there was no reason for the native English speakers to consider the English translation equivalents as plural, since they always lacked a linking element as plural, this pattern is what we expected to find. Crucially, the native Dutch speakers who participated in the English version of the experiment did also not consider the English modifiers as plural. Their response pattern differed from that of the native Dutch speakers in the Dutch version of the experiment but was almost the same as the response pattern of the native English speakers in the English version of the experiment.

These findings suggest that native Dutch speakers treat the linking en as a sign of plural meaning, which corresponds to earlier findings (e.g., Schreuder et al. 1998; Hanssen et al. submitted; Neijt et al. 2004). It even holds for the modifiers with singular concepts. For the English translation equivalents rated by native Dutch speakers, no differences were found for those modifiers which would occur with or without a linking en in Dutch. This indicates that native Dutch speakers rely on the form of the linking en, which is homographic with the plural Dutch suffix -en, when attributing meaning in Dutch but not in English. Although the form of the Dutch linking element appears to originate from either the old Dutch case system (Booij 1996; Van Loey 1969; Van Tiel et al. 2011) or words ending in schwa, the element is related to the plural suffix -en for speakers of modern Dutch and therefore used to express plural meaning (e.g., Banga et al. 2012; Neijt et al. 2002) and interpreted as a plural suffix (e.g., present study; Schreuder et al. 1998; Hanssen et al. submitted; Neijt et al. 2004). 
The native Dutch speakers participating in the English version of the experiment, which did not contain any linking elements, were found to bring along the semantics of Dutch linking en when interpreting conceptually plural modifiers in English but not in the same manner as native Dutch speakers in the Dutch experiment. This indicates that the language people use at a particular moment in time influences their interpretation of compounds.

The question arises whether the results described above really reflect compound interpretation, or are an experimental artefact. We argue for the first option. If the participants had ignored the heads and based their rating only on the modifiers of the compounds, then we would not find the present response pattern. For the compounds containing a linking en, we found a difference between the conceptually singular modifiers (e.g., bananenschil 'banana peel') and the conceptually plural modifiers (e.g., aardbeienjam 'strawberry jam'). For the compounds without linking en, we found a difference between the conceptually singular modifiers (e.g., adreslabel 'address label') and the conceptually plural modifiers (e.g., appeltaart 'apple pie'). These differences suggest that it is not only the modifier that makes the modifier conceptually singular or plural for the native Dutch speakers; it is the combination of modifier and head that results in a conceptually singular or plural concept of the modifier. If the participants had ignored the head, we would not have found this pattern. In this case, the plurality ratings for bananenschil and aardbeienjam would have been the same, and also the plurality ratings for adreslabel and appeltaart. In addition, we had similar results in earlier experiments (e.g., Banga et al. 2012; Neijt et al. 2004). Furthermore, there would be no super singular effect in the present study: The conceptually singular Dutch items without linking en would have been rated the same as the conceptually singular English items. Instead, in our results, these English items were rated the same as the conceptually singular Dutch items with linking en. Given the effects and interactions found in our experiments, we argue that the interpretational effects that are measured can be relevant for everyday reading processes.

In other research, both Kousta et al. (2008) and Boroditsky (2001) investigated linguistic relativity in terms of the influence of a first language on a second language. Kousta et al. (2008) investigated the effects of grammatical gender, which is absent in English but present in Italian. They found Italian-English bilinguals to show the same pattern as English monolinguals when the task was in English and the same pattern as Italian monolinguals when the task was in Italian. Kousta et al. (2008) interpret these results as showing the intraspeaker relativity of semantic representations. Our results are in line with these findings as the Dutch native speakers behaved like the English monolinguals when the task was in English. Unfortunately, we could not compare Dutch bilinguals with Dutch 
monolinguals because the general adult population is more or less bilingual, and certainly the students are highly proficient. At Dutch universities, almost all study books are in English.

Boroditsky (2001) investigated how native English speakers and native Mandarin speakers with English as a second language think about time because time is represented horizontally in English and vertically in Mandarin. Mandarin speakers tended to think about time vertically even when thinking in English, which is in contrast with the findings of the present study. It may thus be the case that the influence of language on thought differs depending on the category. More comparative study is thus a direction for future research.

In conclusion, the results of the present study provide support for the claim that interpretation may be influenced by the morphological form available in a language. When native Dutch speakers interpret modifiers in Dutch compounds, the interpretation of plurality is influenced by the presence or absence of a linking en which is homographic with the Dutch plural suffix -en. When native English speakers interpret modifiers in the English translation equivalents of the Dutch compounds, no such variability is found because, in English, linking elements are generally not present between the two parts of a compound. English native speakers rely on their knowledge of the world to interpret the modifiers in a compound. When native Dutch speakers performed the English version of the experiment and thus did not see linking elements, moreover, they did not bring all their Dutch semantics to the interpretation of the English modifiers. When processing English, native Dutch speakers followed more or less the pattern of native English speakers, which shows the language being used to influence semantic interpretations.

\section{Appendix A: Items}

Compound words with linking en and conceptually singular modifier

\begin{tabular}{llllllll} 
Dutch & CELEX & Google & & English & CELEX & Google \\
\cline { 1 - 2 } \cline { 5 - 6 } bananenschil & 0 & 33100 & & banana skin & - & 125000 \\
bandenpech & 0 & 12000 & & tyre trouble & - & 74300 \\
beddensprei & 0 & 39400 & & bedspread & 2 & 736000 \\
eendenei & 0 & 5180 & & duck egg & - & 1810000 \\
flessenwarmer & 0 & 281000 & & bottle-warmer & - & 226000 \\
ganzenbout & 0 & 2140 & & goose leg & - & 4610 \\
hoedenlint & 0 & 1430 & & hatband & 0 & 23100
\end{tabular}




$\begin{array}{llllll}\text { hondenpoep } & 1 & 427000 & \text { dog dirt } & - & 39900 \\ \text { notendop } & 1 & 1080000 & \text { nut shell } & 1 & 3320000 \\ \text { ruitensproeier } & 0 & 240000 & \text { screen washer } & 0 & 807000 \\ \text { schapenvacht } & 1 & 466000 & \text { sheepskin } & 1 & 5540000 \\ \text { slangenbeet } & 0 & 12900 & \text { snakebite } & 0 & 179000 \\ \text { speldenknop } & 0 & 42300 & \text { pin-head } & 1 & 100000 \\ \text { spinnenweb } & 1 & 204000 & \text { spider web } & - & 209000\end{array}$

Compound words with linking en and conceptually plural modifier

\begin{tabular}{lllllll} 
Dutch & CELEX & Google & English & CELEX & Google \\
\cline { 1 - 4 } aardbeienjam & 1 & 116000 & & strawberry jam & - & 256000 \\
ballenjongen & 1 & 71700 & ball boy & - & 190000 \\
beeldengalerij & 0 & 20000 & statue gallery & - & 15800 \\
bessenstruik & 0 & 15200 & currant bush & - & 11500 \\
boekenplank & 1 & 690000 & bookshelf & - & 4680000 \\
dierendag & 0 & 463000 & animal day & - & 48700 \\
duiventil & 1 & 131000 & dovecote & 0 & 715000 \\
erwtensoep & 1 & 783000 & pea soup & - & 210000 \\
gebarentaal & 1 & 283000 & sign language & 0 & 6720000 \\
hakkenbar & 0 & 788000 & heel bar & - & 151000 \\
hertenkamp & 0 & 222000 & deer park & - & 114000 \\
juwelenkistje & 0 & 18300 & jewel case & - & 2520000 \\
kersenboom & 0 & 130000 & cherry tree & - & 2880000 \\
kleurenfoto & 1 & 243000 & colour photograph & - & 781000 \\
konijnenhok & 0 & 793000 & rabbit hutch & 0 & 2600000 \\
leeuwentemmer & 0 & 47900 & lion tamer & - & 74500 \\
rollenspel & 1 & 2050000 & role play & - & 14700000 \\
rupsenplaag & 0 & 21700 & caterpillar plague & - & 1200 \\
schoenendoos & 1 & 226000 & shoebox & - & 696000 \\
sperziebonenrecept & - & 5290 & green bean recipe & - & 28700 \\
sterrenstelsel & 1 & 8770 & star system & - & 211000 \\
studentendecaan & 0 & 172000 & student counsellor & - & 33800 \\
tandenstoker & 0 & 182000 & toothpick & 1 & 398000 \\
tijdschriftenwinkel & - & 24300 & magazine shop & - & 71200 \\
tomatensaus & 1 & 1440000 & tomato sauce & - & 1200000
\end{tabular}


Compound words without linking en and conceptually singular modifier

\begin{tabular}{lllllll} 
Dutch & CELEX & Google & & English & CELEX & Google \\
\cline { 1 - 3 } adreslabel & - & 168000 & & address label & - & 323000 \\
ballonvaart & 0 & 1010000 & balloon ride & - & 125000 \\
bankdirecteur & 1 & 57500 & & bank manager & - & 575000 \\
beursintroductie & - & 13900 & & market introduction & - & 402000 \\
fietsbel & 0 & 13900 & bicycle bell & - & 43700 \\
huisnummer & 1 & 554000 & house number & - & 1060000 \\
kastdeur & 2 & 122000 & cabinet door & - & 2320000 \\
kerkganger & 0 & 172000 & churchgoer & 0 & 30500 \\
kniereflex & 0 & 1200 & knee reflex & - & 928 \\
koolsla & 0 & 18300 & coleslaw & 1 & 80000 \\
korsetveter & 0 & 513 & corset lace & - & 91000 \\
naambordje & - & 151000 & nameplate & 0 & 747000 \\
oorbel & 0 & 838000 & earring & 1 & 5680000 \\
raamventilator & 0 & 20900 & window fan & - & 364000 \\
schilderijlijst & 0 & 47600 & picture frame & - & 2550000 \\
schroefkop & 0 & 106000 & screw head & - & 136000 \\
smaakversterker & - & 37500 & flavour enhancer & - & 123000
\end{tabular}

Compound words without linking en and conceptually plural modifier

\begin{tabular}{lllllll} 
Dutch & CELEX & Google & & English & CELEX & Google \\
\cline { 1 - 3 } aardappelmesje & 0 & 22300 & & potato knife & - & 4490 \\
appeltaart & 1 & 1080000 & & apple pie & 0 & 1680000 \\
boomchirurg & 0 & 43300 & & tree surgeon & - & 863000 \\
citroenlimonade & 0 & 9400 & lemon drink & - & 124000 \\
dagboek & 19 & 23000000 & daybook & 0 & 75400 \\
diamantmijn & 0 & 30800 & diamond mine & - & 109000 \\
graanhandel & 0 & 59700 & & grain trade & - & 96900 \\
granaatwerper & 0 & 94700 & grenade launcher & & 698000 \\
instrumentmaker & 0 & 125000 & instrument maker & & 310000 \\
kaashandel & 0 & 107000 & & cheese shop & - & 244000 \\
olijfolie & 5 & 6050000 & olive oil & - & 5750000 \\
prijslijst & 0 & 4020000 & price list & 0 & 8680000 \\
straatbende & 0 & 19400 & & street gang & - & 201000 \\
tonijnvangst & - & 10600 & tuna catch & - & 14000
\end{tabular}




\section{Appendix B: Instructions}

\section{B.1 Dutch experiment}

Het eerste deel van een samenstelling heeft soms een meervoudsbetekenis, soms een enkelvoudsbetekenis. Bijvoorbeeld: meervoud voor kleuter in kleuterklas, want het gaat om meerdere kleuters, en enkelvoud voor mannen in mannenstem, want het gaat om de stem van één man. Dat onderscheid noemen we numerositeit.

Het volgende blaadje bevat een woordenlijst. In deze lijst geeft $u$ aan hoe meervoudig $u$ het eerste deel van de samenstelling vindt. Bijvoorbeeld:

$\begin{array}{llllllllll}\text { mannenstem } & \text { enkelvoud } & \bullet & \circ & \circ & \circ & \circ & \circ & \circ & \text { meervoud } \\ \text { kleuterklas } & \text { enkelvoud } & \circ & \circ & \circ & \circ & \bullet & \circ & \circ & \text { meervoud } \\ \text { mierenhoop } & \text { enkelvoud } & \circ & \circ & \circ & \circ & \circ & \circ & \bullet & \text { meervoud } \\ \text { sinaasappelschil } & \text { enkelvoud } & \circ & \circ & \bullet & \circ & \circ & \circ & \circ & \text { meervoud } \\ \text { appelsap } & \text { enkelvoud } & \circ & \circ & \circ & \bullet & \circ & \circ & \circ & \text { meervoud } \\ \text { lippenstift } & \text { enkelvoud } & \circ & \bullet & \circ & \circ & \circ & \circ & \circ & \text { meervoud }\end{array}$

Wanneer $\mathrm{u}$ het eerste deel alleen maar als een enkelvoud kunt interpreteren, dan kleurt $\mathrm{u}$ het eerste rondje in. Kan het eerste deel ook een meervoudsbetekenis hebben, dan kiest $\mathrm{u}$ een van de rondjes rechts daarvan. Hoe meervoudiger $\mathrm{u}$ het eerste deel vindt, hoe meer naar rechts $u$ het rondje inkleurt.

Het gaat om individuele betekenisoordelen. Denk niet te lang na, en laat u vooral leiden door wat het eerst in $\mathrm{u}$ opkomt.

Bedankt voor uw medewerking!

\section{B.2 English experiment}

The first part of a compound word may be a semantic plural or singular. For instance: a plural meaning for bulb in bulb farm, where many bulbs are grown, but a singular meaning for male in male voice, the voice of a man. This distinction is called numerosity.

The following two pages contain a list of compounds. In this list, please indicate your numerosity estimations the first part of each compound. For instance, one's estimations could be as follows: 


$\begin{array}{llllllllll}\text { male voice } & \text { singular } & \bullet & \circ & \circ & \circ & \circ & \circ & \circ & \text { plural } \\ \text { bulb farm } & \text { singular } & \circ & \circ & \circ & \circ & \circ & \bullet & \circ & \text { plural } \\ \text { ant hill } & \text { singular } & \circ & \circ & \circ & \circ & \circ & \circ & \bullet & \text { plural } \\ \text { orange peel } & \text { singular } & \circ & \circ & \bullet & \circ & \circ & \circ & \circ & \text { plural } \\ \text { apple juice } & \text { singular } & \circ & \circ & \circ & \bullet & \circ & \circ & \circ & \text { plural } \\ \text { lipstick } & \text { singular } & \circ & \bullet & \circ & \circ & \circ & \circ & \circ & \text { plural }\end{array}$

If your interpretation is singular, then colour the first circle. If the first part of the compound can also have a plural interpretation, choose one of the circles to the right. The more plural you think the first part is, the more to the right your choice of circle to color.

Note that the task concerns individual meaning judgments. Do not think about things too much, and let your initial intuition guide you.

Thank you for your cooperation!

\section{Acknowledgements}

This research was supported by the Netherlands Organization for Scientific Research (NWO) Grant No. 360-70-361 to the third and fourth authors. We thank Lee Ann Weeks for help with a revision, and the associate editors and anonymous reviewers for their helpful comments. Thanks to Gary Wood of the University of Sheffield and Martijn Bentum for their help with data collection. Also thanks to Didier Hodiamont, Marloes van den Akker, and Martijn Bentum for the classification of the items.

\section{References}

Banga, Arina, Esther Hanssen, Anneke Neijt \& Robert Schreuder. In press. Preference for linking element $e n$ in Dutch noun-noun compounds: Native speakers and second language learners of Dutch. Morphology.

Banga, Arina, Esther Hanssen, Robert Schreuder \& Anneke Neijt. (2012). How subtle differences in orthography influence conceptual interpretation. Written Language and Literacy 15(2), 185-208.

Booij, Geert E. 1996. Verbindingsklanken in samenstellingen en de nieuwe spellingregeling [Linking phonemes in compounds and the new spelling system]. Nederlandse Taalkunde 2, 126-134.

Booij, Geert E. 2007. The Grammar of Words. An Introduction to Linguistic Morphology. Oxford: Oxford University Press. 
Boroditsky, Lera. 2001. Does language shape thought? Mandarin and English speakers' conceptions of time. Cognitive Psychology 43, 1-22.

Boroditsky, Lera. 2003. Linguistic relativity. In L. Nadel (ed.), Encyclopedia of Cognitive Science, 917-922. London: Macmillan.

Boroditsky, Lera, Orly Fuhrman \& Kelly McCormick. 2011. Do English and Mandarin speakers think about time differently? Cognition 118, 123-129.

Bowerman, Melissa \& Choi, Soonja. 2007. Shaping meanings for language: universal and language-specific in the acquisition of spatial semantic categories. In B. Bokus \& G. W. Shugar (eds.), Psychologia języka dziecka, 386-424. Gdansk: Wydawnictwo Psychologiczne.

Bauer, Laurie. 2003. Introducing Linguistic Morphology. Edinburgh: Edinburgh University Press.

Chen, Jenn Yeu. 2007. Do Chinese and English speakers think about time differently? Failure of replicating Boroditsky (2001). Cognition 104(2), 427-436.

Gumperz, John J. \& Stephen C. Levinson. 1997. Rethinking linguistic relativity. Current Anthropology 32, 613-623.

Hanssen, Esther, Arina Banga, Robert Schreuder \& Anneke Neijt. Submitted. Regular noun plurals as modifiers in spoken Dutch compounds.

Hanssen, Esther, Arina Banga, Robert Schreuder \& Anneke Neijt. In press. Semantic and prosodic effects of Dutch linking elements. Morphology (special issue).

Humboldt, von, Wilhelm. 1836. Über die Verschiedenheit des menschlichen Sprachbaus und ihren Einfluss auf die geistige Entwicklung des Menschengeschlechts. Berlin: Druckerei der Könichlichen Akademie der Wissenschaften.

January, David \& Edward Kako. 2007. Re-evaluating evidence for linguistic relativity: Reply to Boroditsky (2001). Cognition 104, 417-426.

Kousta, Stavroula Thaleia, David P. Vinson \& Gabriella Vigliocco. 2008. Investigating linguistic relativity through bilingualism: The case of grammatical gender. Journal of Experimental Psychology: Learning, Memory, and Cognition 34, 843-858.

Krott, Andrea, R. Harald Baayen \& Robert Schreuder. 2001. Analogy in morphology: modeling the choice of linking morphemes in Dutch. Linguistics 39(1), 51-93.

Lewis, M. Paul (ed.). 2009. Ethnologue: Languages of the World. Dallas, TX: SIL International. Online version: <http://www.ethnologue.com/> [Accessed January 2013].

Loey, A., van. 1969. Middelnederlandse spraakkunst I: Vormleer [Middle Dutch grammar I: Morphology]. Groningen: Wolters-Noordhoff.

Losonsky, Michael. 1999. Wilhelm van Humboldt: On language. On the diversity of human language construction and its influence on the mental development of the human species. Cambridge: Cambridge University Press.

Lucy, John A. 1992. Language and the diversity of thought: a reformulation of the linguistic relativity hypothesis. Cambridge: Cambridge University Press.

McDonough, Laraine, Soonja Choi \& Jean M. Mandler. 2003. Understanding spatial relations: Flexible infants, lexical adults. Cognitive Psychology 46, 229-259.

Miwa, Koji, Gary Libben, R. Harald Baayen \& Sally Rice. 2008. Lexical activations in picture comparison: A cross-linguistic approach to the relation between language and thought in the mental lexicon. In Proceedings of the 6th International Conference of Cognitive Science, 230-232. Seoul, Korea.

Neijt, Anneke, Loes Krebbers \& Paula Fikkert. 2002. Rhythm and semantics in the selection of linking elements. In H. Broekhuis \& P. Fikkert (eds.), Linguistics in the Netherlands, 2002, 117-127. Amsterdam/Philadelphia: John Benjamins Publishing Company. 
Neijt, Anneke, Robert Schreuder \& R. Harald Baayen. 2004. Seven years later. The effect of spelling on interpretation. In L. Cornips \& J. Doetjes (eds.), Linguistics in the Netherlands, 134-145. Amsterdam/Philadelphia: John Benjamins Publishing Company.

Roberson, Debi, Jules Davidoff, Ian R. L. Davies \& Laura L. Shapiro. 2004. Color categories: Evidence for the cultural relativity hypothesis. Cognitive Psychology 50, 378-411.

Roberson, Debi, Ian R. L. Davies \& Jules Davidoff. 2000. Colour categories are not universal: Replications and new evidence from a Stone-age culture. Journal of Experimental Psychology 129, 369-398.

Sapir, Edward. 1985 [1949]. Selected writings in language, culture, and personality. Edited by D. G. Mandelbaum. Berkeley/Los Angeles: University of California Press.

Schreuder, Robert, Anneke Neijt, Femke van der Weide \& R. Harald Baayen. 1998. Regular Plurals in Dutch Compounds: Linking Graphemes or Morphemes? Language and Cognitive Processes 13(5), 551-573.

Tiel, van, Bob, Margit Rem \& Anneke Neijt. 2011. De historische ontwikkeling van de tussenklank in Nederlandse nominale samenstellingen [The history of the linking element in Dutch noun-noun compounds]. Nederlandse Taalkunde 16(2), 120-140.

Trabant, Jürgen. 2000. How relativistic are Humboldt's “Weltansichten”? In M. Pütz \& M. H. Verspoor (eds.), Explorations in Linguistic Relativity, 25-44. Amsterdam/Philadelphia: John Benjamins Publishing Company.

Verkuyl, Henk J. 2007. De gedachte aan een meervoud in het eerste lid van een samenstelling: aan wat denkt men dan eigenlijk? [Thinking of a plural for the first part of a compound: What does one actually think of?] In F. Moerdijk \& A. van Santen (eds.), Leven met woorden. Afscheidsbundel voor Professor Piet van Sterkenburg, 457-466. Leiden: Brill.

Whorf, Benjamin Lee. 1956. Language, thought and reality: Selected writings of Benjamin Lee Whorf. Edited by John B. Carrol. Cambridge, MA: MIT Press. 